\title{
PERANAN SERTA TANTANGAN PROFESIONAL GURU SEBAGAI SEBUAH PROFESI
}

\author{
Monalisa Rahman \\ Email: 2010128220010@ulm.ac.id \\ Program Studi Pendidikan IPS Fakultas Keguruan dan Ilmu Pendidikan \\ Universitas Lambung Mangkurat \\ Banjarmasin
}

\begin{abstract}
Abstrak
Profesi keguruan pada hakikatnya adalah suatu pernyataan terbuka yang menyatakan bahwa seseorang tersebut mengabdikan dirinya pada suatu jabatan karena orang itu merasa terpanggil untuk menjabat dan melaksanakan tugasnya sebagai pendidik. Guru yang taat terhadap kode etik akan mendorong mereka berperilaku sesuai dengan norma yang berlaku oleh etika profesi yang ditetapkan oleh organisasi atau perkumpulan profesinya selama menjalankan tugas profesionalnya. Untuk menjaga harkat dan martabat profesi guru memiliki peranan, hak dan kewajiban yang harus dijalankannya sebagai seorang pendidik. Kualitas pendidikan dan profesionalisme guru saling berkorelasi hingga keduanya tidak bisa terlepas terutama dalam proses pencapaian tujuan pendidikan. Satu yang memengaruhi kualitas pendidikan yaitu profesionalisme guru sebab guru merupakan penentu dari keberhasilan dan kegagalan dari suatu proses pembelajaran hingga hal ini akan berpengaruh pada masa depan peserta didik. Adapun komponen yang terdapat dalam kompetensi keprofesionalan seorang guru adalah kompetensi pedagogik, kompetensi profesional, kompetensi sosial dan kompetensi kepribadian.
\end{abstract}

\section{PENDAHULUAN}

Profesi berasal dari bahasa Inggris profession yang berakar dari bahasa latin profesus yang artinya mengakui atau menyatakan mampu atau ahli dalam suatu bentuk pekerjaan. Pekerjaan disini dengan sendirinya melahirkan pelayanan berkeahlian khusus yang pada gilirannya akan menuntut adanya etika yang tumbuh. Karena adanya faktor pengetahuan terspesialisasi, keajengan etis seorang anggota profesi hanya akan dapat dinilai secara tepat oleh anggota lain dari profesi tersebut. Jadi profesi adalah suatu pekerjaan atau jabatan yang menuntut keahlian (expertrce), artinya profesi sebagai suatu 
pekerjaan tidak bisa dilakukan oleh sembarang orang yang tidak terlatih dan tidak disiapkan secara khusus untuk melakukan pekerjaan itu (Nasihin, 2008: 1).

Profesi pada hakikatnya ialah suatu pernyataan atau suatu janji terbuka yang menyatakan bahwa seseorang itu mengabdikan dirinya pada suatu jabatan atau pelayanan karena orang tersebut merasa terpanggil untuk menjabat pekerjaan tersebut. Berdasarkan definisi diatas meskipun profesi adalah pekerjaan seumur hidup dan ada konsekuensi ekonomis atas suatu pekerjaan di bidang profesi tersebut, akan tetapi titik fokusnya utamanya terletak pada pengabdian dan tanggunng jawab moril sesuai bidang keilmuan profesi. Dengan demikian tanggung jawab insan profesi tidak hanya kepada atasan atau pemerintah, tetapi juga menjadi pembeda antara profesi dengan bidang pekerjaan lain yang bukan profesi (Susanto, 2020: 14).

Secara umum syarat suatu pekerjaan untuk dapat dikategorikan menjadi suatu profesi ialah memiliki spesialisasi ilmu, memilki kode etik dalam menjalankan profesi, memiliki organisasi profesi, diapresiasi masyarakat, sebagai panggilan hidup, dilengkapi kecakapan diagnostik dan mempunyai klien yang jelas (Susanto, 2020: 14-16).

Berdasarkan UU RI No.14 tahun 2005 tentang Guru dan Dosen Pasal 1, Guru adalah pendidik profesional dengan tugas utama mendidik, mengajar, membimbing, mengarahkan, melatih, menilai dan mengevaluasi peserta didik pada pendidikan anak usia dini jalur pendidikan formal, pendidikan dasar dan pendidikan menengah. Dosen adalah pendidik profesional dan ilmuan dengan tugas utama mentransformasikan, mengembangkan dan menyebarluaskan ilmu pengetahuan, teknologi dan seni melalui pendidikan, penelitian dan pengabdian kepada masyarakat.

Menurut Rickey (1987) sebagaimana dikutif Soetjipto dan Kosasi (2009: 17) mengemukakan ciri-ciri guru sebagai profesi, yakni (i) adanya komitmen dari para guru bahwa jabatan itu mengharuskan anggotanya menjunjung tinggi martabat kemanusiaan lebih dari pada mencari keuntungan sendiri, (ii) suatu profesi mensyaratkan orangnya mengikuti persiapan profesional dalam jangka waktu tertentu, (iii) guru harus selalu menambah pengetahuan agat terus menerus berkembang dalam jabatannya, (iv) memiliki kode etik jabatan, (v) memiliki kemampuan intelektual menjawab masalah-masalah yang dihadapi, (vi) selalu ingin belajar terus-menerus mengenai bidang keahlian yang ditekuni, 
(vii) menjadi anggota dari suatu organisasi profesi dan (viii) jabatan itu dipandang sebagai suatu karir hidup.

Guru merupakan suatu porfesi yang berarti suatu jabatann yang memerlukan keahlian khusus sebagai guru dan tidak dapat dilakukan oleh sembarang orang diluar bidang pendidikan. Meskipun pada kenyataan masih ditemukan guru yang tidak memiliki latar belakang pendidikan bidang keguruan. Seorang guru berhubungan dengan kegiatan profesinya diharuskan mengetahui dan bisa menerapkan beberapa prinsip mengajar agar ia dapat melaksanakan tugasnya secara profesional (Susanto, 2020: 17) yaitu sebagai berikut:

a. Guru harus dapat membangkitkan perhatian siswa pada materi pelajaran yang diberikan serta dapat menggunakan berbagai media dan sumber belajar yang bervariasi.

b. Guru harus dapat membangkitkan minat siswa untuk aktif dalam berpikir serta mencari dan menemukan sendiri pengetahuan.

c. Guru harus dapat membuat urutan dalam pemberian pelajaran dan penyesuaiannya dengan usia dan tahap tugas perkembangan siswa.

d. Guru perlu menghubungkan pelajaran yang diberikan dengan pengetahuan yang telah dimiliki siswa agar siswa menjadi mudah dalam memahami pelajaran yang diterimanya.

e. Guru diharapkan dapat menjelaskan unit pelajaran secara berulang-ulang hingga tanggapan siswa menjadi jelas.

f. Guru wajib memerhatikan dan memikirkan hubungan antara mata pelajaran dan praktik nyata dalam kehidupan sehari-hari.

g. Guru harus mejaga konsentrasi belajar para siswa dengan cara memberikan kesempatan berupa pengalaman secara langsung, mengamati, meneliti dan menyimpulkan pengetahuan yang didapatnya.

h. Guru harus mengembangkan sikap siswa dalam membina hubungan sosial, baik dalam kelas ataupun diluar kelas.

i. Guru harus menyelidiki dan mendalami perbedaan siswa secara individual supaya dapa melayani siswa sesuai dengan perbedaannya itu. 
Guru dapat melaksanakan penilaian yang efektif serta menggunakan hasilnya untuk mengetahui kemajuan siswa dan melakukan perbaikan dan pengembangan. Seiring dengan kemajuan teknologi dan informasi yang telah demikian pesat berkembang, guru tidak hanya bertindak sebagai penyedia informasi, tetapi juga harus mampu bertindak sebagai fasilitator, motivator, dan pembimbingan yang lebih banyak memberikan kesempatan kepada peserta didik untuk mencari dan mengolah sendiri informasi. Dengan demikian, keahlian guru harus terus dikembangkan dan tidak hanya terbatas pada penguasaan prinsip mengajar.

\section{PERAN GURU SEBAGAI SEBUAH PROFESI}

Guru dapat diklasifikasikan sebagai sebuah profesi, menurut National Education Assocition (NEA), syarat guru sebagai profesi terpenuhi karena guru mempunyai kriteria, diantaranya: (i) jabatan yang melibatkan aktvitas intelektual, (ii) jabatan yang menggeluti suatu batang tubuh ilmu yang khusus, (iii) jabatan yang memerlukan persiapan professional yang lama, (iv) jabatan yang melibatkan latihan dalam jabatan yang berkesinambungan, (v) jabatan yang menjanjikan karir hidup dalam keanggotaan yang tetap, (vi) jabatan yang menentukan standar sendiri, (vii) jabatan yang lebih mementingkan layanan di atas keuntungan pribadi, (viii) jabatan yang memiliki organisasi profesional yang kuat dan terjalin erat.

Adapun guru sebagai profesi terpenuhi karena guru mempunyai kriteria diantaranya memiliki kode etik dan organisasi profesional yang kuat dan terjalin erat. Soejipto dan Raflis Kosasi berpendapat bahwa kode etik suatu profesi ialah norma-norma yang harus diindahkan oleh setiap anggota profesi didalam melaksanakan tugas profesinya dan dalam hidupnya di masyarakat. Norma-norma itu berupa petunjuk bagi anggota profesi tentang bagaimana mereka melaksanakan profesinya dan laranagn yakni ketentuan tentang apa yang tidak boleh dilakukan oleh mereka, bukan hanya dalam melaksanakan tugas profesi mereka, tetapi juga terkait dengan tingkah laku anggota profesi pada umumnya dalam pergaulannya sehari-hari dalam masyarakat.

Secara umum, kode etik diperlakukan dengan beberapa alasan, antara lain, sebagai berikut: 
a. Untuk melindungi pekerjaan sesuai dengan ketentuan dan kebijakan yang telah ditetapkan berdasarkan perundang-undangan yang berlaku.

b. Untuk mengontrol terjadinya ketidakpuasan dan persengketaan dari pelaksana, sehingga dapat menjaga dan meningkatkan stabilitas internal dan eksternal pekerjaan.

c. Melindungi para praktisi di masyarakat, terutama dalam hal adanya kasus-kasus penyimpangan tindakan, melindungi anggota masyarakat dari praktek yang menyimpang dari ketentuan yang berlaku (Susanto, 2020: 26-27).

Dalam upaya mewujudkan kode etik guru Indonesia, perlu memperhatikan faktorfaktor yang dirasakan sebagai kendala, faktornya ialah kualitas pribadi guru, latar pendidikan guru, prasarana dan sarana pendidikan, sistem pendidikan, kebijakan pemerintah, kedudukan, karier dan kesejahteraan guru.

Sanksi bagi guru yang melanggar kode etik guru sudah disiapkan sesuai dengan perundang-undangan yang berhubungan dengan profesi guru. Jenis pelanggaran yang dilakukan guru terhadap kode etik guru Indonesia dapat digolongkan dengan tiga jenis yaitu pelanggaran kategori ringan, sedang dan berat. Sanksi yang diberatkan kepada guru yang melanggar tidak hanya berupa hukuman saja melainkan pemberian sanksi itu juga menrupakan upaya pembinaan yang dilakukan oleh profesi guru serta untuk menjaga harkat dan martabat guru. Guru yang melanggar kode etik juga dapat melakukan pembelaan diri atau tanpa bantuan organisasi profesi guru atau penasehat hukum (Susanto, 2020: 28).

Adapun fungsi dari sanksi terhadap pelanggaran kode etik profesi yakni untuk mencegah guru melakukan pelanggaran terhadap pelanggaran kode etik profesi guru, untuk membina guru yang melanggar agar tidak melakukan pelanggaran lagi dan menjaga citra dan martabat profesi guru.

Guru akan berperan dengan baik sesuai kode etik profesi guru jika didukung oleh sumberdaya pembelajaran yang memadai. Guru dapat berperan sebagai pendidik bagi peserat didik jika didukung dengan kepekaan orang tua dan masyarakat untuk menjalankan sistem pendidikan sesuai peran masing-masing sehingga tercipta suasana pembelajaran yang sesuai dengan kebutuhan perkembangan belajar siswa. Penanaman nilai-nilai pendidikan yang dilaksanakan oleh guru tidak akan membawa dampak posotif bagi siswa jika di lingkungan keluarga dan masyarakat nilai-nilai tersebut tidak diikuti. Keadaan 
tersebut hanya akan mengakibatkan putusnya proses pendidikan, maka secara praktis kode etik guru akan membawa dampak luas dalam proses pendidikan jika diikuti dengan berbagai pihak terkait dalam proses pendidikan (Susanto, 2020: 30).

Organisasi profesi keguruan merupakan wadah perkumpulan orang-orang yang mempunyai suatu keahlian dan keterampilan mendidik yang dipersiapkan melalui proses pedidikan dan latihan yang relatif lama, serta dilakukan dalam lebaga tertentu yang dapat dipertanggung jawabkan (Wau, 2014: 44).

Tujuan organisasi ini ialah mempertinggi kesadaran sikap, mutu, dan kegiatan profesi guru serta meningkatkan kesejahteraan guru. Dalam PP No.38 tahun 1992, pasal 61, ada lima misi dan tujuan organisasi kependidikan, yakni: meningkatkan dan mengembangkan (i) karier, (ii) kemampuan, (iii) kewenangan, (iv) martabat dan (v) kesejahteraan seluruh tenaga kependidikan. Sedangkan visinya adalah terwujudnya seluruh tenaga kependidikan yang profesional (Pidarta, 2007: 292). Selain itu juga organisasi profesi guru memiliki kewenangan yakni:

a. Menetapkan dan menegakkan kode etik guru.

b. Memberikan bantuan hukum kepada guru.

c. Memberikan perlindungan profesi guru.

d. Melakukan pembinaan dan pengembangan profesi guru.

e. Memajukan pendidikan nasional.

Organisasi profesi keguruan berfungsi sebagai pemersatu seluruh anggota profesi dalam kiprahnya menjalankan tugas keprofesiannya dan memiliki fungsi peningkatan kemampuan profesional profesi tersebut.

Berikut jenis-jenis organisasi keguruan yang ada di Indonesia, yakni sebagai berikut: Persatuan Guru Republik Indonesia (PGRI), Musyawarah Guru Mata Pelajaran (MGMP), Ikatan Sarjana Pendidikan Indonesia (ISPI), dan Ikatan Petugas Bimbingan Indonesia (IPBI).

Guru sebagai suatu profesi di bidang pendidikan mempunyai hak dan kewajiban yang menyangkut dunia pendidikan yang digeluti. Hak-hak guru merupakan apa saja yang didapatkan oleh seseorang yang memiliki profesi guru, dan kewajiban guru adalah apa saja yang harus dilakukakan seorang guru dalam melaksanakan profesinya. Hak dan kewajiban 
guru ini dituangkan dalam UU No. 14 Tahun 2005 tentang guru dan dosen sehingga setiap guru mendapatkan perlindungan terhadap hak yang dimiliki dan kewajiban yang harus dilaksanakan. (Heri Susanto, 2020: 38)

Tugas guru bukan hanya sebagai suatu profesi, tetapi juga sebagai suatu tugas kemanusiaan dan kemasyarakatan. Tugas guru sebagai suatu profesi menuntut kepada guru untuk mengembangkan profesionalitas diri sesuai perkembangan ilmu pengetahuan dan teknologi. Mendidik, mengajar, dan melatih anak didik adalah tugas guru sebagai suatu profesi. Tugas guru sebagai pendidik ialah meneruskan dan mengembangkan nilai-nilai hidup kepada peserta didik. Tugas guru sebagai pelatih berarti mengembangkan keterampilan dan menerapkannya dalam kehidupan demi masa depan peserta didik (Djamarah, 2000: 37).

Jika diidentifikasi dari filosofi pendidikan Indonesia yang dicetuskan Ki Hadjar Dewantara "ing ngarso sung tulodo, ing madya mangun karso, tutwuri handayani" maka peran guru adalah sebagai:

a. Role model (ing ngarso sung tulodo), memberikan teladan kepada siswa karena fungsi guru menjadi pemimpin siswa dalam kegiatan pembelajaran

b. Motor penggerak (ing madya mangun karso), guru harus menjadi penggerak atau mendorong inovasi dalam proses pendidikan dan penggerak peradaban dengan cara mengarahkan siswa untuk melakukan yang benar.

c. Motivator (tutwuri handayani).

Djamarah(2000: 42-49) menguraikan peranan yang dijalankan guru sebagai pendidik. Semua peranan diharapkan dari guru ialah (i) Sebagai korektor, guru harus bisa membedakan mana nilai yang baik dan mana nilai yang buruk. (ii) sebagai inspirator, dalam peran ini guru diharuskan untuk menjadi role model bagi peserta didik dan dapat memberikan petunjuk bagaimana cara belajar yang baik. (iii) Sebagai informan, guru harus dapat memberikan informasi perkembangan IPTEK, selain bahan pelajaran untuk setiap mata pelajaran yang telah diprogramkan dalam kurikulum. (iv) Sebagai organisator, guru mempunyai aktivitas pengelolaan kegiatan akademik, menyusun tata tertib kelas/sekolah, menyusun rencana pembelajaran sesuai kalender akademik, dan sebagainya. Semuanya harus diorganisir sehingga tujuan pembelajaran dapat tercapai. (v) Sebagai motivator, guru 
hendaknya mampu mendorong peserta didik agar bergairah dan aktif belajar. (vi) Sebagai inisiator, guru harus dapat menjadi pencetus ide-ide kemajuan dalam pendidikan dan pengajaran. (vii) sebagai fasilitator, guru mengelola sumberdaya yang tersedia sedemikian rupa sehingga memungkinkan siswa dapat memperoleh pengalaman belajar yang sesuai dengan tingkat perkembangan mereka. (viii) guru sebagai pembimbing. (ix) demonstrator, guru harus kreatif untuk menunjukkan langsung kepada peserta didik kemampuan yang harus dipelajari. (x) Sebagai pengelola kelas, guru hendaknya dapat mengelola kelas dengan baik, karena kelas adalah tempat berhimpun semua peserta didik dan guru dalam rangka menerima bahan pelajaran dari guru. (xi) Sebagai mediator, guru harus memahami bagaimana siswa berinteraksi dan merespon suatu kondisi. (xii) sebagai supervisi pembelajaran, guru harus menunjukkan kemampuan untuk menawarkan alternatif solusi atas permasalahan yang ditemukan. (xiii) dan sebagai evaluator.

Dalam menjalankan tugas profesinya, guru mempunyai hak dan kewajiban yang harus dilaksanakan. Hak guru ialah suatu yang harus didapatkan atau diterima olehnya setelah ia melaksanakan kewajibannya sebagai guru. Sedangkan kewajiban guru adalah sesuatu yang harus dilaksanakan oleh guru dalam menjalankan profesinya.

Hak dan kewajiban guru sebagai pendidik diatur dalam peraturan perundangundangan yang berkaitan dengan pendidikan. Dalam UU No. 14 Tahun 2005 tentang guru dan dosen pada bagian kedua mengenai hak dan kewajiban pada pasal 14, adapun hak yang dimiliki oleh seorang guru sebagai berikut:

a. Memperoleh penghasilan di atas kebutuhan hidup minimum dan jaminan kesejahteraan sosial.

b. Mendapatkan promosi dan penghargaan sesuai dengan tugas dan prestasi kerja.

c. Memperoleh perlindungan dalam melaksanakan tugas dan hak atas kekayaan intelektual.

d. Memperoleh kesempatan untuk meningkatkan kompetensi.

e. Memperoleh dan memanfaatkan sarana dan prasarana pembelajaran untuk menunjang kelancaran tugas keprofesionalan. 
f. Memiliki kebebasan dalam memberikan penilaian dan ikut menentukan kelulusan, penghargaan, dan atau sanksi kepada peserta didik sesuai dengan kaidah pendidikan, kode etik guru, dan peraturan perundang-undangan.

g. Memperoleh rasa aman dan jaminan keselamatan dalam melaksanakan tugas.

h. Memiliki kebebasan untuk berserikat dalam organisasi profesi.

i. Memiliki kesempatan untuk berperan dalam penentuan kebijakan pendidikan

j. Memperoleh kesempatan untuk mengembangkan dan meningkatkan kualifikasi akademik dan kompetensi.

k. Memperoleh pelatihan dan pengembangan profesi dalam bidangnya.

Adapun kewajiban Guru dalam UU No. 14 tahun 2005 tentang guru dan dosen, pada pasal 20 yakni:

a. merencanakan pembelajaran, melaksanakan proses pembelajaran yang bermutu, serta menilai dan mengevaluasi hasil pembelajaran.

b. Mengembangkan dan meningkatkan kualifikasi akademik dan kompetensi secara berkelanjutan sejalan dengan perkembangan ilmu pengetahuan, teknologi dan seni.

c. Bertindak objektif dan tidak diskriminatif atas dasar pertimbangan jenis kelamin, agama, suku, ras, dan kondisi fisik tertentu, atau latar belakang keluarga, dan status sosial ekonomi peserta didik dalam pembelajaran.

d. Menjunjung tinggi peraturan perundang undangan, hukum dan kode etik guru, serta nilai nilai agama dan etika.

e. Memelihara dan memupuk persatuan dan kesatuan bangsa.

Berikut penjelasan mengenai peran, hak dan kewajiban profesi guru, maka sebaiknya siswa dapat menghargai guru dengan baik, karena yang kita pahami bahwa banyaknya tugas guru yang harus dilakukannya tidak hanya untuk mendidik tapi juga berbagai hal lainnya. Pekerjaan guru dapat dipandang suatu profesi yang secara menyeluruh harus memiliki kepribadian yang baik dan mental yang kuat, karena mereka menjadi contoh bagi siswanya dan masyarakat sekitarnya. Dzakiyh Drajat menyatakan tentang kepribadian guru sebagai "setiap guru hendaknya memiliki kepribadian yang akan di contoh dan diteladani oleh siswa (Drajat, 2005:10). 
Guru harus baik mempunyai perilaku dan moral yang baik, karena perilaku guru akan dilihat oleh siswa dan akan di ikuti oleh siswa. Jadi guru harus selalu mencontohkan perilaku yang baik dan moral yang baik pula. Karena besarnya tanggung jawab guru terhadap siswa, guru tidak pernah memusuhi siswanya meskipun suatu saat siswa yang berbuat kurang sopan kepada orang lain, bahkan dengan sabar dan bijaksana guru memberikan nasehat bagaimana cara bertingkah laku yang sopan pada orang lain (Susanto, 2020: 50).

\section{GURU INDONESIA DAN TANTANGAN PROFESIONALISME}

Kualitas pendidikan dan profesionalisme guru saling berkorelasi sehingga keduanya tidak bisa terlepas terutama dalam proses pencapaian tujuan pendidikan. Satu yang memengaruhi kualitas pendidikan yaitu profesionalisme guru sebab guru merupakan penentu dari keberhasilan dan kegagalan dari suatu proses pembelajaran hingga hal ini akan berpengaruh pada masa depan peserta didik. Saat ini kualitas pendidikan di Indonesia masih jauh tertinggal dari negara-negara lain. Kondisi yang ada sampai saat ini yaitu tingkat profesionalisme guru masih jauh dari harapan sedangkan prestasi serta hasil akademik peserta didik dipengaruhi oleh guru. Untuk dapat mengajar peserta didik secara optimal, guru harus mempunyai kualifikasi profesional yang diintegrasikan dengan proses pembelajaran yang dilakukan guru tersebut. Oleh karena itu, perlu diadakan terobosan atau inovasi agar tingkat profesionalisme guru di Indonesia dapat menjadi lebih baik dan agar pendidikan di Indonesia dapat semakin berkembang serta dapat bersaing dengan negara lain (Ratnasari, 2019: 235)

Menurut Wardani (2012) kemampuan profesional sebagai guru termasuk dalam penguasaan utuh dari implementasi kompetensi guru serta kemampuan menjalankan tugas dengan mengutamakan kebaikan dan kepuasaan peserta didik. Menurut Putri dan Imaniyati (2017) profesi pendidik ialah profesi yang sangat berperan dalam kehidupan suatu bangsa dikarenakan kedudukan pendidikan yang sangat penting dalam konteks kehidupan bangsa. Pendidik merupakan komponen yang paling berperan dalam suatu proses pendidikan sehingga kualitas pendidikan banyak dipengaruhi oleh kualitas dari pendidik itu sendiri dalam menjalankan peran dan tugasnya di masyarakat. Maka dari itu mengembangkan 
profesi pendidik menjadi ketentuan mutlak bagi proses memajukan suatu bangsa, meningkatnya kualitas pendidik juga akan mendorong pada peningkatan kualitas pendidikan baik dari segi proses maupun hasil (Ratnasari, 2019: 236).

Kemudian, mengapa guru harus memiliki kompetensi profesional karena kalau tidak memiliki kompetensi profesional maka tidak bisa mengajarkan kepada siswa. Kompetensi profesional guru merupakan kemampuan dasar yang harus dimiliki seorang guru, meliputi guru harus mempunyai pengetahuan tentang belajar dan belajar tingkah laku manusia, mempunyai pengetahuan dan menguasai bidang yang dibinanya, mempunyai sikap yang tepat tentang diri sendiri, sekolah dan bidang studinya dan guru harus mempunyai keterampilan dalam teknik mengajar. Jadi kemampuan dasar ini harus dimiliki oleh seorang guru kalau tidak maka tidak bisa dikatakan seorang guru karena tidak memiliki kompetensi profesional guru.

Adapun ketentuan yang terdapat dalam UU No.14 tahun 2005 tentang guru dan dosen meliputi kompetensi pedagogik, kompetensi kepribadian, kompetensi sosial dan kompetensi profesional yang diperolah dari pendidikan profesi.

a. Kompetensi pedagogik merupakan kemampuan guru dalam mengelola proses pembelajaran peserta didik, indikatornya antara lain guru mampu menguasai karakteristik siswa dari aspek fisik, moral, sosial budaya, emosional, dan intelektual, menguasai teori belajar dan prinsip-prinsip pembelajaran yang mendidik, mengembangkan kurikulum yang terkait dengan bidang pengembangan yang diampu, menyelenggarakan kegiatan pengembangan yang mendidik, memanfaatkan TIK untuk kepentingan penyelenggaraan kegiatan pengembangannya yang mendidik, memfasilitasi pengembangan potensi siswa untuk mengaktualiasikan berbagai potensi yang dimiliki, berkomunikasi secara efektif, empatik dan santun dengan siswa, menyelenggarakan penilaian dan evaluasi proses dan hasil belajar, memanfaatkan hasil penilaian dan evaluasi untuk kepentingan pembelajaran, dan melakukan tindakan reflektif untuk peningkatan kualitas pembelajaran.

b. Kompetensi kepribadian merupakan kemampuan kepribadian yang mantap, stabil, dewasa, arif dan bijaksana, berwibawa, berakhlak mulia, menjadi teladan bagi siswa dan masyarakat, mengevaluasi kinerja sendiri, dan mengembangkan diri secara 
berkesimabungan. Indikatornya antara lain: bertindak sesuai dengan norma agama, hukum, sosial dan kebudayaan nasional Indonesia, menampilkan diri sebagai pribadi yang jujur, berakhlak mulia, dan teladan bagi siswa dan masyarakat, menampilkan diri sebagai pribadi yang mantap, stabil, dewasa, arif, dan berwibawa dan menunjukkan etos kerja, tanggungjawab yang tinggi, rasa bangga menjadi guru, dan rasa percaya diri, menjunjung tinggi kode etik profesi guru.

c. Kompetensi sosial merupakan kemampuan guru untuk memahami dirinya sebagai bagian dari masyarakat dan mampu mengembangkan tugas sebagai anggota masyarakat dan warga negara (Satori, dkk, 2008: 215). Indikatornya antara lain adalah: bersifat inklusif, bertindak objektif, serta tidak diskriminatif karena pertimbangan jeni kelamin, agama, ras, kondisi fisik, latar belakang keluarga dan status sosial ekonomi, berkomunikasi secara efektif, empatik, dan santun dengan sesama pendidik, tenaga kependidikan, orang tua dan masyarakat, beradaptasi di tempat bertugas di seluruh wilayah Republik Indonesia yang memiliki keragaman sosial budaya, dan mampu berkomonikasi dengan komunitas profesi sendiri dan profesi lain secara lisan dan tulisan atau bentuk lain.

d. Kompetensi profesional merupakan kemampuan dan kewenangan guru dalam menjalankan profesi keguruannya artinya guru yang mahir dalam melaksanakan profesinya dapat disebut sebagai guru yang kompeten dan profesional (Susanto, 2020: 63). Indikatornya antara lain adalah: menguasai materi, struktur, konsep dan pola pikir keilmuan yang mendukung mata pelajaran yang diampu, menguasai standar kompetensi dan kompeteni dasar mata pelajaran bidang pengembangan yang diampu, mengembangkan materi pembelajaran yang diampu secara kreatif, mengembangkan keprofesionalan secara berkelanjutan dengan melakukan tindakan reflektif, dan mampu memanfaatkan TIK untuk berkomunikasi dan pengembangan diri.

Berikut tadi dijelaskan komponen-komponen apa saja yang harus dimiliki guru untuk bisa disebutsebagai guru yang profesional. 


\section{SIMPULAN}

Profesi pada hakikatnya ialah suatu pernyataan atau suatu janji terbuka yang menyatakan bahwa seseorang itu mengabdikan dirinya pada suatu jabatan atau pelayanan karena orang tersebut merasa terpanggil untuk menjabat pekerjaan tersebut. Berdasarkan definisi diatas meskipun profesi adalah pekerjaan seumur hidup dan ada konsekuensi ekonomis atas suatu pekerjaan di bidang profesi tersebut, akan tetapi titik fokusnya utamanya terletak pada pengabdian dan tanggunng jawab moril sesuai bidang keilmuan profesi. Dengan demikian tanggung jawab insan profesi tidak hanya kepada atasan atau pemerintah, tetapi juga menjadi pembeda antara profesi dengan bidang pekerjaan lain yang bukan profesi (Susanto, 2020: 14).

Secara umum syarat suatu pekerjaan untuk dapat dikategorikan menjadi suatu profesi ialah memiliki spesialisasi ilmu, memilki kode etik dalam menjalankan profesi, memiliki organisasi profesi, diapresiasi masyarakat, sebagai panggilan hidup, dilengkapi kecakapan diagnostik dan mempunyai klien yang jelas (Susanto, 2020: 14-16).

Berdasarkan UU RI No.14 tahun 2005 tentang Guru dan Dosen Pasal 1, Guru adalah pendidik profesional dengan tugas utama mendidik, mengajar, membimbing, mengarahkan, melatih, menilai dan mengevaluasi peserta didik pada pendidikan anak usia dini jalur pendidikan formal, pendidikan dasar dan pendidikan menengah. Dosen adalah pendidik profesional dan ilmuan dengan tugas utama mentransformasikan, mengembangkan dan menyebarluaskan ilmu pengetahuan, teknologi dan seni melalui pendidikan, penelitian dan pengabdian kepada masyarakat.

Guru merupakan suatu porfesi yang berarti suatu jabatann yang memerlukan keahlian khusus sebagai guru dan tidak dapat dilakukan oleh sembarang orang diluar bidang pendidikan. Meskipun pada kenyataan masih ditemukan guru yang tidak memiliki latar belakang pendidikan bidang keguruan. Seorang guru berhubungan dengan kegiatan profesinya diharuskan mengetahui dan bisa menerapkan beberapa prinsip mengajar agar ia dapat melaksanakan tugasnya secara profesional (Susanto, 2020: 17).

Guru dapat melaksanakan penilaian yang efektif serta menggunakan hasilnya untuk mengetahui kemajuan siswa dan melakukan perbaikan dan pengembangan. Seiring dengan kemajuan teknologi dan informasi yang telah demikian pesat berkembang, guru tidak hanya 
bertindak sebagai penyedia informasi, tetapi juga harus mampu bertindak sebagai fasilitator, motivator, dan pembimbingan yang lebih banyak memberikan kesempatan kepada peserta didik untuk mencari dan mengolah sendiri informasi. Dengan demikian, keahlian guru harus terus dikembangkan dan tidak hanya terbatas pada penguasaan prinsip mengajar.

Adapun guru sebagai profesi terpenuhi karena guru mempunyai kriteria diantaranya memiliki kode etik dan organisasi profesional yang kuat dan terjalin erat. Soejipto dan Raflis Kosasi berpendapat bahwa kode etik suatu profesi ialah norma-norma yang harus diindahkan oleh setiap anggota profesi didalam melaksanakan tugas profesinya dan dalam hidupnya di masyarakat. Norma-norma itu berupa petunjuk bagi anggota profesi tentang bagaimana mereka melaksanakan profesinya dan laranagn yakni ketentuan tentang apa yang tidak boleh dilakukan oleh mereka, bukan hanya dalam melaksanakan tugas profesi mereka, tetapi juga terkait dengan tingkah laku anggota profesi pada umumnya dalam pergaulannya sehari-hari dalam masyarakat.

Menurut Wardani (2012) kemampuan profesional sebagai guru termasuk dalam penguasaan utuh dari implementasi kompetensi guru serta kemampuan menjalankan tugas dengan mengutamakan kebaikan dan kepuasaan peserta didik. Menurut Putri dan Imaniyati (2017) profesi pendidik ialah profesi yang sangat berperan dalam kehidupan suatu bangsa dikarenakan kedudukan pendidikan yang sangat penting dalam konteks kehidupan bangsa. Pendidik merupakan komponen yang paling berperan dalam suatu proses pendidikan sehingga kualitas pendidikan banyak dipengaruhi oleh kualitas dari pendidik itu sendiri dalam menjalankan peran dan tugasnya di masyarakat. Maka dari itu mengembangkan profesi pendidik menjadi ketentuan mutlak bagi proses memajukan suatu bangsa, meningkatnya kualitas pendidik juga akan mendorong pada peningkatan kualitas pendidikan baik dari segi proses maupun hasil (Ratnasari, 2019: 236).

Kemudian, mengapa guru harus memiliki kompetensi profesional karena kalau tidak memiliki kompetensi profesional maka tidak bisa mengajarkan kepada siswa. Kompetensi profesional guru merupakan kemampuan dasar yang harus dimiliki seorang guru, meliputi guru harus mempunyai pengetahuan tentang belajar dan belajar tingkah laku manusia, mempunyai pengetahuan dan menguasai bidang yang dibinanya, mempunyai sikap yang 
tepat tentang diri sendiri, sekolah dan bidang studinya dan guru harus mempunyai keterampilan dalam teknik mengajar. Jadi kemampuan dasar ini harus dimiliki oleh seorang guru kalau tidak maka tidak bisa dikatakan seorang guru karena tidak memiliki kompetensi profesional guru.

Adapun komponen-komponen apa saja yang harus dimiliki guru untuk dapat disebut sebagai guru yang profesional yaitu adalah kompetensi profesional, pedagogik, sosial, dan kompetensi kepribadian.

\section{REFERENSI}

Efendi, I., Prawitasari, M., \& Susanto, H. (2021).ImplementasiPenilaianPembelajaranPadaKurikulum 2013 Mata PelajaranSejarah.Prabayaksa: Journal of History Education, 1(1), 21-25.

Susanto, H. (2020). ProfesiKeguruan. Banjarmasin: FKIP UniversitasLambungMangkurat.

Susanto, H., \&Akmal, H. (2018).EfektivitasPenggunaanAplikasiPembelajaranBerbasis Mobile Smartphone Sebagai Media PengenalanSejarahLokalMasaRevolusiFisik Di Kalimantan Selatan PadaSiswaSekolahMenengahAtas.HISTORIA: Jurnal Program StudiPendidikanSejarah, 6(2), 197-206.

Susanto, H., Irmawati, I., Akmal, H., \& Abbas, E. W. (2021).Media Film DokumenterMasuknya Islam Ke Nusantara danPengaruhnyaTerhadapKeterampilanBerpikirKritisSiswa.HISTORIA: Jurnal Program StudiPendidikanSejarah, 9(1).

Syaharuddin, S., \& Susanto, H. (2019).SejarahPendidikan Indonesia (Era PraKolonialisme Nusantara sampaiReformasi). Banjarmasin: FKIP UniversitasLambungMangkurat.

Ratnasari, Y. T. (2019). PROFESIONALISME GURU DALAM PENINGKATAN MUTU PENDIDIKAN. Revitalisasi Manajemen Pendidikan Anak Usia Dini (PAUD) di Era Revolusi Industri 4.0.

Nasihin, S. (2008). Profesi Guru Dalam Konsep Dan Teori. Jurnal Administrasi Pendidikan, 8(2). 